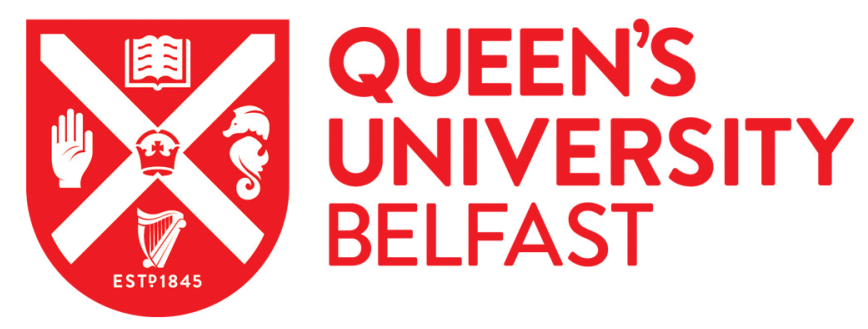

\title{
Recruitment settings, delivery contexts, intervention techniques and outcomes of health promotion programmes for young adults with intellectual and developmental disabilities: A systematic review
}

Maine, A., Brown, M., Ski, C., Thompson, D. R., Marsh, L., \& O'Leary, L. (2020). Recruitment settings, delivery contexts, intervention techniques and outcomes of health promotion programmes for young adults with intellectual and developmental disabilities: A systematic review. Research in Developmental Disabilities, 99, [103592]. https://doi.org/10.1016/j.ridd.2020.103592

Published in:

Research in Developmental Disabilities

Document Version:

Peer reviewed version

Queen's University Belfast - Research Portal:

Link to publication record in Queen's University Belfast Research Portal

\section{Publisher rights}

Copyright 2020 Elsevier.

This manuscript is distributed under a Creative Commons Attribution-NonCommercial-NoDerivs License

(https://creativecommons.org/licenses/by-nc-nd/4.0/), which permits distribution and reproduction for non-commercial purposes, provided the author and source are cited.

\section{General rights}

Copyright for the publications made accessible via the Queen's University Belfast Research Portal is retained by the author(s) and / or other copyright owners and it is a condition of accessing these publications that users recognise and abide by the legal requirements associated with these rights.

Take down policy

The Research Portal is Queen's institutional repository that provides access to Queen's research output. Every effort has been made to ensure that content in the Research Portal does not infringe any person's rights, or applicable UK laws. If you discover content in the

Research Portal that you believe breaches copyright or violates any law, please contact openaccess@qub.ac.uk. 


\begin{abstract}
Background: People with intellectual and developmental disabilities (IDD) are at risk of developing long term health conditions, and a preventative health agenda research is emerging. However, little is known about the recruitment settings, delivery contexts, intervention techniques and outcomes of health promotion programmes for this population. Therefore, the aim of this review was to synthesize and evaluate these characteristics.

Method: A systematic review of studies identified from multiple databases on healthy lifestyle interventions for adolescents and young people with IDD was conducted. Data were synthesized and evaluated using a logic model. Quality of rigour was also assessed.

Results: Sixteen geographically diverse studies were selected and evaluated. Participants were most commonly recruited from schools, with interventions typically taking place in a gym setting and involving physical activity training.

Conclusions: This review indicates that physical activity and dietary interventions in people with IDD may lead to lifestyle changes, however more robust evidence is required. Educational settings are conducive, with settings beyond schools requiring further consideration.
\end{abstract}

\title{
What this paper adds
}

The review provides a comprehensive overview of the study settings, delivery contexts, intervention techniques and outcomes in health research targeting adolescents and young people with IDD. This has implications for how future studies in this area are conducted, as research with a preventative agenda has hitherto recruited primarily from school settings. The recruitment advantages of these settings are highlighted, such as approaching large participant groups and support from educational professionals. However, it is demonstrated that additional settings, such as further education institutions, would potentially provide similar advantages 
yet reach wider and more independent samples in terms of capacity to make autonomous lifestyle choices.

Evidence to date has demonstrated the efficacy of physical activity interventions on lifestyle change in people with IDD. However, whilst many of the intervention techniques necessitated specialist equipment and subsequently gym settings, there were also simpler, effective techniques, which improved physical activity outcomes that could be carried out in any setting. Such techniques could be supported by educational professionals, potentially leading to sustained programme adherence and improved health outcomes.

\section{Introduction}

Globally poor dietary and exercise habits of adolescents and young people in the typically developing are adding to an increased prevalence of long-term health conditions (Fletcher et al., 2018). The World Health Organisation (WHO, 2017) predicts a 13\% global mortality rise between 2002 and 2020 in four of the most prominent chronic diseases: type 2 diabetes (T2D), cardiovascular disease (CVD), cancer and chronic obstructive pulmonary disease (WHO, 2019). Physical activity programmes have demonstrated success in reducing the risk of developing long term health conditions and improving quality of life (QoL) in adolescents and young people (Ekelund et al., 2013; Granger et al. 2017; Gopinath et al. 2012; Yates et al. 2016). In addition, preventing the onset of long term conditions may lead to lower healthcare expenditure, such as reduced patient care and treatment costs. For example, costs associated with type 2 diabetes may be reduced by 40-60\% (Gillies et al. 2007).

Poor dietary and exercise habits are also a concern for adolescents and young people with intellectual and developmental disabilities (IDD) as they are at significant risk of developing long-term health conditions such as diabetes, obesity and hypertension and are more likely to experience poorer physical health when compared to young people in the 
typically developing population (Krahn and Fox 2015; Truesdale and Brown, 2017; Allerton and Emerson, 2011). Further, genetic conditions such as Prader Willi and Down syndrome are likely to cause obesity at a young age, severely increasing the likelihood of T2D in later life (O'Shea et al., 2018), one of the four most prominent global long term health conditions. In addition, lower socio-economic status has been found to increase the risk of poor health by as much as $20-50 \%$ in adolescents and young people with IDD (Emerson and Hatton, 2007), further compounded by transport and membership costs, reduced opportunities for recreational exercise, lower health literacy, less access to healthy diets (Melville et al., 2008), and being over prescribed psychotropic medications (Trollor, Salomon, and Franklin, 2016). It is therefore imperative that people with IDD benefit from the same intervention approaches as those afforded to the typically developing population so that they may be supported to reduce the risk of developing long term health conditions and experience increased QoL, in accordance with the Adults with Incapacity Act (2000) and the Disability Equality Act (2010).

Recent literature reviews of the health of young people and adolescents with IDD have highlighted that whilst there are potentially significant benefits from the development of health intervention programmes, there remain methodological issues around recruitment and study design, which are often impacted upon by recruitment and delivery setting (Bertapelli et al. 2016, Jeng et al., 2017). Research has indicated that physical activity outcomes may be influenced by intervention settings, for example residential communities (Chow et al., 2016), schools (Haerens et al., 2008), and the workplace (Iwasaki et al., 2017). A key component of psychosocial interventions for people with IDD is social support, which is instrumental to a sense of self-efficacy (Maine et al., 2017), for example through facilitating recording and reflection of progress as well as positive feedback and reinforcement of key messages. While the type of support may vary depending on setting, it is important to consider which social settings are selected for intervention programmes, as these may act as mediators to the success 
of outcomes. This review therefore aimed to build an understanding of which recruitment and delivery settings are being used, and how these relate to intervention delivery contexts and techniques and healthy lifestyle outcomes, such as increased physical activity, reduced sedentary behaviour, and health literacy. Such an understanding may be used to guide the development of future interventions aimed at supporting adolescents and young people with IDD. Therefore, the aim of this review is to identify the intervention settings, techniques, and healthy lifestyle outcomes of health promotion programmes being provided to adolescents and young people with IDD.

\section{Methods}

\subsection{Search strategy}

A systematic search was conducted of PsycINFO, PubMed, CINAHL, ERIC, and the British Education Index electronic databases to identify relevant psychosocial and educational studies. Search terms included Intellectual disab* OR learning disab* OR developmental disab* OR mental retardation AND young people or adolescents or teenagers or college students AND health intervention or health promotion or health prevention. Papers were included if the adolescents and young people were between 10 and 24 years, were written in English and were published over a 20-year period between January 1999 and January 2019. Additional age parameters were selected using the WHO (2013) definition of key terms, with adolescents as 10 to 19 years, and young people as 10 to 24 years.

\subsection{Study selection and data extraction}

As each search engine differed on age parameter settings, it was necessary to make further selections from abstracts and within methodology sections. A second reviewer repeated this procedure to validate the searches and selections. A third reviewer undertook an independent 
secondary evaluation of selected texts, and a final selection was made through consensus, as advocated by the Cochrane systematic review toolbox (2019). The Preferred Reporting Items for Systematic Reviews and Meta-analyses (PRISMA) guidelines (Moher, Liberati, Tetzlaff, \& Altman, 2009) were adhered to through this process. Data extraction criteria was agreed by all reviewers through consensus (Table 1). Extraction was carried out by the first reviewer, and verified by the second, and involved spreadsheet entry of means and standard deviations of participant characteristics, study designs, methodology and outcomes, and key recommendations. The PRISMA diagram (Figure 1) outlines the selection process.

Insert figure 1 here

\subsection{Inclusion criteria}

Results were included where the following criteria were employed:

- Health promotion programmes that targeted adolescents and/or young people with IDD

- Study designs which included randomized controlled trials (RCTs) and feasibility studies

- Adolescents and young people were between 10 and 24 years of age

- English language only

\subsection{Exclusion criteria}

- Studies focusing on developmental disabilities only

- Studies outside of specified date range

- Full text not available

\subsection{Quality of evidence}


Quality of evidence was assessed by the first review using the Effective Public Health Practice Project (2008), a tool comprising a series of component ratings which include the representativeness of samples to populations, study design, control of confounding variables, validity and reliability of measures, and study drop-outs. This process was verified by a second reviewer.

\subsection{Synthesis of intervention techniques and outcomes}

Adopting guidelines of Kneale, Thomas, and Harris (2015), a logic model was constructed to visually explore interlinking components of the studies. Logic models increasingly play a useful role in the reviewing of interventions (Anderson et al., 2011), and in this review the model helped elucidate the complex relationship between the intervention settings, techniques, and outcomes.

Insert Table 1 here

\section{Results}

Data extracted from the studies are summarised in Table 1.

\subsection{Settings and locations}

Of the 16 studies identified, four were conducted in the U.S. (Chen et al., 2015; Curtin et al., 2013; Hubbard et al., 2015; Stanish and Temple, 2011), two each in Australia (Lennox et al., 2016; Shields et al., 2013) and Belgium (Boer et al., 2014; Elmahgoub et al., 2009), and one each in New Zealand (Hinkson et al., 2013), Poland (Jankowicz-Szymanska et al., 2012), Spain (Ordonez et al., 2014), The Netherlands (Kiewik et al., 2016), Taiwan (Wu et al., 2017), South 
Korea (Lee, Lee, and Song, 2016), the U.K. (Maine, Brown, Dickson, and Truesdale, 2019) and China (Kong et al., 2019).

\subsection{Participant characteristics}

The overall mean participant age was 17.7 (SD 2.5) years and ranged from 7 (Hinkson et al. 2013) to 39 (Maine et al. 2019) based on available data.

The mean percentage of female participants in studies was $46.7 \%$, and included an allfemale sample (Ordonez et al. 2014); removing this would provide a mean of $42.8 \%$. Ethnicity was not reported in the studies, with the exception of Curtin et al. (2013) who reported a 4.8\% Hispanic and $95 \%$ White sample. Down syndrome was the most commonly reported disability condition, and was the specific focus of four studies (Chen et al., 2015; Curtin et al., 2013; Ordonez et al., 2014; and Shields et al., 2013), and was further highlighted as a predominant condition amongst participants by Hinkson et al., 2013; Jankowicz-Szymanska et al., 2012; Stanish and Temple, 2011; Wu et al., 2017). This may reflect upon the genetic characteristics associated with Down syndrome, such as overweight and obesity, and cardiovascular conditions which can limit opportunity for physical activity (Emerson and Hatton, 2007). A range of other conditions described across studies as secondary included autism, fragile $\mathrm{X}$ syndrome, foetal alcohol syndrome (FAS), Prader-Willi syndrome, hydrocephalus, pervasive developmental disorder, Sotos syndrome, Steinert syndrome, and global developmental delay. However, the sizes of these subgroups were not commonly reported. These may have acted as additional barriers to implementing healthy lifestyles. However, as sizes of these subgroups were not commonly reported, it is difficult to assess the extent of their impact.

\subsection{Measured outcomes}

Measured outcomes (and significant results) are described below in the logic model (Figure 2). The most commonly measured outcome was body composition $(N=8)$, which included 
standardised measures of BMI, waist circumference, body fat mass, fat-free mass, skeletal muscle mass and body fat percentage (Boer et al., 2014; Elmahgoub et al. 2009; Kong et al., 2019; Ordonez et al., 2014; Stanish and Temple, 2011; Wu et al., 2017).

This was followed by physical fitness $(N=5)$, which encompassed the maximal cardiopulmonary exercise test, and six-minute walk test (Boer et al., 2014; Elmahgoub et al. 2009; Hinkson et al., 2013); the sit-and-reach test, dominant hand grip test, and modified curlups (Stanish and Temple, 2011; Kong et al., 2018); and one minute sit-ups (Wu et al., 2017; Kong et al., 2016).

Other notable measured outcomes included balance, which was measured in five studies, and utilized measures including static balance and one-legged standing/unipedal stance test (Jankowicz-Szymanska et al., 2012, Wu et al., 2016, Lee et al., 2016; Kong et al., 2016). Strength $(\mathrm{N}=4)$ involved the sit-to-stand test, repetition maximum, hand grip strength, and muscle fatigue resistance (Elmagoub et al, 2009, Lee et al., 2016); dominant hand grip test and modified curl-ups (Stanish and Temple, 2011), and one-repetition maximum tests (Shields et al., 2013).

\subsection{Context and content}

The logic model (Figure 2) and associated table (Table 2) below, aligns recruitment and delivery context to intervention techniques and to statistically significant outcomes, thus providing a visual outline of the relationship between these study characteristics.

Insert Figure 1 and Table 2 here

The majority of the studies recruited participants from educational classroom-based settings $(\mathrm{n}=11)$, yet more interventions took place in a gym setting $(\mathrm{N}=8)$, than in classrooms $(\mathrm{N}=$ 
5). This reflects on the prevalent intervention approach of using physical activity equipment such as stack weights and treadmills, for which a gym setting was necessary.

Classroom-based interventions took an educational approach, with a focus on diet, physical activity, and the benefits of medical check-ups, additionally enhanced by parental input. Decreased weight and increased physical activity levels were achieved as significant outcomes, as well as an increased likelihood of medical checks. The use of the gym lead to significant improvements in body composition, physical fitness, muscular strength, cardiovascular levels, and balance.

A sports laboratory $(\mathrm{N}=1)$ was another setting used and revealed that aerobic training led to decreased blood pressure, waist circumference and lipids, together with executive function changes. Additionally, a classroom-based intervention in a university room $(\mathrm{N}=1)$ was used for dietary and parental education leading led to lower body weight and increased physical activity.

\subsection{Recommendations}

Most studies made recommendations for future research and practice, with some exceptions (Elmahgoub et al. 2009, Shields et al. 2013). Six recommendations related to intervention modifications such as training for peer support (Stanish and Temple, 2011) and consultation with family and supporters (Curtin et al., 2013; Hinkson et al. 2013; Kiewik et al. 2016). Other recommendations were methodological, focusing on improving rigour through increased sample sizes (Chen et al., 2015; Kong et al., 2019) and longitudinal follow ups (Hubbard et al. 2015; Ordonez et al. 2014). Pertinent to this review, Hinkson et al. (2013) recommended that the schools were appropriate settings for these interventions, while Hubbard et al. (2015) advocated for educational settings beyond schools, a view further supported by Maine et al. (2019) who recommended continued delivery in further education institutions. 


\subsection{Quality evaluation}

Study quality is summarized in Table 3. The assessed quality of the studies was not high, with three received 'Strong' global ratings (Boer et al., 2014; Chen et al., 2015; Shields et al., 2013). Individual component ratings are provided in separate tables, in the supplementary materials. The EPHPP tool does not heavily penalize on study design. Small sampled feasibility studies may therefore be awarded a similar overall rating to cluster RCTs. As RCT studies were a minority in the present review ( $\mathrm{n}=5$, Lee et al., 2016; Lennox et al., 2016; Kiewik et al., 2016; Kong et al., 2019; Shields et al., 2013), the EPHPP was a suitable tool for providing a balanced comparison across studies. The majority of 'Weak' component ratings $(n=8)$ were due to study drop-out rates, highlighting a common issue with participation adherence. The second most common 'Weak' component ratings were due to 'Confounders' where studies had not reported balancing of baseline demographics. This was noted in five of the 16 studies (Curtin et al., 2013; Hinkson et al., 2013; Hubbard et al., 2015; Stanish and Temple 2012; Wu et al., 2017) (Table 4).

Insert Table 3 here

\section{Discussion}

This is the first systematic review of the recruitment settings, delivery contexts, and intervention techniques and outcomes of health promotion programmes aimed specifically at adolescents and young people with IDD. The included studies mainly recruited participants from schools (mean age 17.7 years). In recruiting a young age group, the studies steered towards a preventative agenda; reducing the risk of unhealthy lifestyle-related diseases later in later life. This approach is advocated in the typically developing population and is a key 
initiative of the Medical Research Council (2019). However, despite recruitment from schools, interventions were typically physical activity-based and took place in settings with sports facilities, such as gyms, where equipment facilitated successful outcomes. These were primarily improved muscle strength, cardiovascular fitness, and balance. However, the longterm impact of gym-based interventions aimed at young people with IDD in schools may be limited given that the school leaving age is usually around 18 years of age, thus negating the possibility of sustaining these health benefits and outcomes. It could be further argued that while the gym settings may be the most appropriate in terms of achieving targeted outcomes, positive health outcomes were achieved irrespective of the setting, which is a significant finding warranting further attention.

Other barriers, including lower socio-economic status and transport and membership costs, significantly reduced opportunities for adolescents and young people with IDD accessing sports facilities (Emerson and Hatton, 2007; Emerson and Baines, 2010). Indeed, Coates et al. (2017) described similar issues leading to low levels of continued adherence to interventions. It is therefore arguable that day-to-day settings, such as vocational or educational placements, may carry fewer barriers and increase the likelihood of long-term adherence, yet improving access to gyms and sports centres has to be part of the preventative global health agenda to ensure that adolescents and young people with IDD can avail of the same opportunities as their peers, thereby sustaining and maintaining positive health outcomes.

This finding may also be true of the three studies which took place in research settings (Boer et al., 2014, Chen et al., 2015, and Curtin et al., 2013), which may be removed from everyday activities. Notably, not all of the physical activity techniques required equipment such as stretching and core strength training. Therefore, it may be possible to research the impact of these techniques in a setting outside of a gym. 
Classroom-based interventions mainly targeted diet and physical activity enhanced by social support, and statistically significant outcomes in weight loss and increased physical activity were identified. However, recruitment of participants with IDD has been reported as challenging, due to barriers such as care staff attitudes and organisational policies (Bossink et al., 2017; Cartwright et al., 2017). In such a pragmatic sampling approach, researchers would have approached single gatekeepers in the first instance to gain approval to access large groups, rather than individuals. This setting may therefore be advantageous in terms of numbers, and extend the possibility of recruiting larger samples through multi-centre recruitment.

The majority of the health promotion programmes for adolescents and young people in the general population has been conducted in school settings. A meta-analysis (Sobol, Rabinowitz, and Gross, 2013) of 32 RCTs of intervention programmes which reduced obesity in a school setting found that more recent studies were more effective as these were longer and involved parental contribution. In terms of intervention outcomes, $78 \%(25 / 32)$ of programmes increased physical activity; 62.5\% (20/32) reduced sedentary behaviour; $81 \%(26 / 32)$ increased a healthy diet; and 78\% (25/32) reduced unhealthy diet, which are similar to the present review. However, these outcomes were primarily achieved though educational sessions, rather than physical activity techniques such as strength and aerobic training, which led to successful outcomes in the present review. A subsequent step would be to explore these techniques in an educational setting and ascertain their applicability to adolescents and young people with IDD.

In addition to settings and techniques, study outcome measures are likely to have influenced the choice of setting and intervention technique, and as such may have played a mediator role. For example, whilst physical fitness and strength outcomes utilised a wide range of measures which were often not context dependent and could be thus be carried out in accessible settings, cardiovascular and metabolic fitness outcomes occasionally required the 
use of laboratory equipment. This may be regarded as a limitation in this review as it is not fully clear the extent to which outcome measures rather than settings or techniques are responsible for significant results. However, the logic model and table highlights that the most commonly reported outcomes and significant results are likely to be aligned to intervention techniques.

As this review provides evidence of a significant focus on avoiding unhealthy lifestyles in adolescents and young people, an educational setting beyond school could be considered in future research (Hubbard et al., 2015). With the exception of Maine et al. (2019) who explored a further education college setting, all education setting studies were school-based. In Scotland, for example, 6\% of adolescents and young people with IDD (aged 16-34 years) were in further education during 2017 (Scottish Commission of Learning Disabilities, 2017), which is a relatively unexplored area in healthy lifestyle intervention research. As the mean age of further education students ranges from 16-26 years (Association of Colleges, 2018), it is evident that studies focussing on preventing chronic diseases in adolescents and young people with IDD have thus far not adequately addressed their specific health needs. These findings provide a rationale for further research to be conducted in further education colleges supporting people with IDD. A UK Department of Education commissioned review (Carroll et al., 2017) highlighted that the majority of evidence for IDD curriculum approach comes from schools, rather than further education colleges, and that there is a dearth of health research in this area, with focus instead directed at pedagogy and challenging behaviour, despite health being a component of the life skills curriculum. It therefore follows that there is a need to identify what healthy lifestyle messages are currently being delivered, and how these could be enhanced through an evidence base. As with the interventions delivered within a school setting highlighted in this review, components which provide education on diet are also of key 
importance. These may also be an aspect of current further education life skills curriculum, and further research is required in this setting.

\section{Conclusions}

Knowledge acquired from two decades of research on healthy lifestyle intervention programmes for adolescents and young people with IDD is limited, due to poor methodological concerns such as small sample sizes and a lack of robust study designs. However, programmes which focused on increased strength and aerobic training, and dietary education demonstrated some improvements and offered potential pointers for successful lifestyle modification in young people with IDD. This review has highlighted that intervention settings have a close relationship with techniques and should therefore be carefully selected. Physical activity training may not require physical activity settings. Educational settings may provide accessibility and social support, and a research gap in the further education college context has been identified. Therefore, further research might consider physical activity training sessions within further education college settings as part of the preventative health strategy required to support intervention techniques and positive health outcomes for adolescents and young people with IDD. 


\section{References}

Allerton, L, Welch, V., \& Emerson, E. (2011). Health inequalities experienced by children and young people with intellectual disabilities: A review of literature from the United Kingdom. Journal of Intellectual Disabilities, 15, 269-278. https://doi.org/10.1177/1744629511430772

Anderson, L. M., Petticrew, M., Rehfuess, E., Armstong, R., Ueffing, E., Baker, P., Francis, D., \& Tugwell, D. (2011). Using logic models to capture complexity in systematic reviews. Research Synthesis Methods, 2, 33-42.

Association of Colleges (2018). Research and Stats. Retrieved from: https://www.aoc.co.uk/about-colleges/research-and-stats

Bertapelli, F., Pitetti, K.,Agiovlasitis, S., \& Guerra-Júnior, G. (2016). Overweight and obesity in children and adolescents with Down syndrome-prevalence, determinants, consequences, and interventions: A literature review. Research in Developmental Disabilities, 57, 181-192. 10.1016/j.ridd.2016.06.018.

Boer, P. H., Meeus, M., Terblanche, E., Rombaut, L., De Wandele, I., Hermans, L., \& Calders, P. (2014). The influence of sprint interval training on body composition, physical and metabolic fitness in adolescents and young people with intellectual disability: A randomized controlled trial. Clinical Rehabilitation, 28, 221-231. doi:10.1177/0269215513498609

Bossink, L.W., van der Putten, A.A., \& Vlaskamp, C. (2017). Understanding low levels of physical activity in people with intellectual disabilities: A systematic review to identify barriers and facilitators. Research in Developmental Disabilities, 68, 95-110.

Carroll, J., Bradley, L., Crawford, H., Hannant, P., Johnson, H., \& Thompson, A. (2017). SEN support: A rapid evidence assessment. UK Government (Home Office). 
Cartwright, L., Reid, M., Hammersley, R., \& Walley, R.M., 2017. Barriers to increasing the physical activity of people with intellectual disabilities. British Journal of Learning Disabilities, 45, 47-55.

Chen, C. C., Ringenbach, S. D. R., Crews, D., Kulinna, P. H., \& Amazeen, E. L. (2015). The association between a single bout of moderate physical activity and executive function in young people with Down syndrome: A preliminary study. Journal of Intellectual Disability Research, 59, 589-598. doi:10.1111/jir.12163

Chow, B. C., Huang, W., Choi, P., \& Pan, C. Y. (2016). Design and methods of a multicomponent physical activity program for adults with intellectual disabilities living in group homes. Journal of exercise science and fitness, 14(1), 35-40. doi:10.1016/j.jesf.2016.06.002

Coates, V., Slevin, M., Carey, M., Slater, P., \& Davies, M. (2017). Declining structured diabetes education in those with type 2 diabetes: A plethora of individual and organisational reasons. Patient Education and Counseling. http://doi.org/10.1016/j.pec.2017.10.013

Curtin, C., Bandini, L. G., Must, A., Gleason, J., Lividini, K., Phillips, S., ... Fleming, R. K. (2013). Parent support improves weight loss in adolescents and young people with down syndrome. Journal of Pediatrics, 163, 1402-1408.e1. doi:10.1016/j.jpeds.2013.06.081

Cochrane Community (2019) Systematic Review Toolbox. Retrieved from: https://community.cochrane.org/help/tools-and-software/systematic-review-toolbox Effective Public Health Practice Project. (2007). Quality Assessment Tool for Quantitative Studies. Retrieved from: https://merst.ca/wpcontent/uploads/2018/02/qualityassessment-tool_2010.pdf - 
Ekelund, U., Luan, J., Sherar, L. B., Esliger, D. W., Griew, P., Cooper, A., \& the International Children's Accelerometry Database Collaborators. (2012). Moderate to vigorous physical activity and sedentary time and cardiometabolic risk factors in children and adolescents. Journal of the American Medical Association, 307, 704-712. doi:10.1001/jama.2012.156.

Elmahgoub, S. M., Lambers, S., Stegen, S., Van Laethem, C., Cambier, D., \& Calders, P. (2009). The influence of combined exercise training on indices of obesity, physical fitness and lipid profile in overweight and obese adolescents with mental retardation. European Journal of Pediatrics, 168, 1327-1333. doi:10.1007/s00431-009-0930-3

Emerson, E., \& Baines, S., (2010). Health Inequalities \& People with Learning Disabilities in the UK: 2010, Learning Disabilities Observatory Retrieved from https://www.improvinghealthandlives.org.uk

Emerson, E., \& Hatton, C. (2007). The contribution of socio-economic position to the health inequalities faced by children and adolescents with intellectual disabilities in Britain. American Journal on Mental Retardation, 112, 140-50

Fletcher, E.A., McNaughton, S.A., Crawford, D., Cleland, V., Della Gatta, J., Hatt, J., Dollman, J. \& Timperio, A., (2018). Associations between sedentary behaviours and dietary intakes among adolescents. Public Health Nutrition, 21, 1115-1122.

Gillies, C. L., Abrams, K. R., Lambert, P. C., Cooper, N. J., Sutton, A. J., Hsu, R. T., \& Khunti, K. (2007). Pharmacological and lifestyle interventions to prevent or delay type 2 diabetes in people with impaired glucose tolerance: systematic review and metaanalysis. British Medical Journal, 334(7588), 299. doi:10.1136/bmj.39063.689375.55

Gopinath, B., Hardy, L, Baur, L. A., Bulutsky, G., \& Mitchell, P. (2012). Physical activity and sedentary behaviors and health-related quality of life in adolescents. Pediatrics, 130, e167-e174. doi:10.1542/peds.2011-3637. 
Granger, E., Di Nardo, F., Harrison, A., Patterons, L., Holmes, R., \& Verma, A. (2017). A systematic review of the relationship of physical activity and health status in adolescents. European Journal of Public Health, 27(Suppl. 2), 100-106. doi:10.1093/eurpub/ckw187.

Haerens, L., Craeynest, M., Deforche, B., Maes, L., Cardon, G., \& De Bourdeaudhuij, I. (2008). The contribution of psychosocial and home environmental factors in explaining eating behaviours in adolescents. European Journal of Clinical Nutrition, 62(1), 5159. http://doi.org/10.1038/sj.ejcn.1602681

Hubbard, K. L., Bandini, L. G., Folta, S. C., Wansink, B., Eliasziw, M., \& Must, A. (2015). Impact of a Smarter Lunchroom intervention on food selection and consumption among adolescents and young people with intellectual and developmental disabilities in a residential school setting. Public Health Nutrition, 18, 361-371. doi:10.1017/S1368980014000305

Hinckson, E. A., Dickinson, A., Water, T., Sands, M., \& Penman, L. (2013). Research in Developmental Disabilities Physical activity, dietary habits and overall health in overweight and obese children and youth with intellectual disability or autism. Research in Developmental Disabilities, 34, 1170-1178. doi:10.1016/j.ridd.2012.12.006

Iwasaki, Y., Honda, S., Kaneko, S., Kurishima, K., Honda, A., Kakinuma, A., \& Jahng, D. (2017). Exercise Self-Efficacy as a Mediator between Goal-Setting and Physical Activity: Developing the Workplace as a Setting for Promoting Physical Activity. Safety and Health at Work, 8(1), 94-98. http://doi.org/10.1016/j.shaw.2016.08.004 Jankowicz-szymanska, A., Mikolajczyk, E., \& Wojtanowski, W. (2012). Research in Developmental Disabilities The effect of physical training on static balance in young 
people with intellectual disability. Research in Developmental Disabilities, 33, 675681. doi:10.1016/j.ridd.2011.11.015

Jeng, S. C., Chang, C. W., Liu, W. Y., Hou, Y. J., \& Lin, Y. H. (2017). Exercise training on skill-related physical fitness in adolescents with intellectual disability: A systematic review and meta-analysis. Disability and Health Journal, 10, 198-206. doi:10.1016/j.dhjo.2016.12.003

Kiewik, M., Vandernagel, J. E. L., Kemna, L. E. M., Engels, R. C. M. E., \& Dejong, C. A. J. (2016). Substance use prevention program for adolescents with intellectual disabilities on special education schools: A cluster randomised control trial. Journal of Intellectual Disability Research, 60, 191-200. doi:10.1111/jir.12235

Kneale, D., Thomas, J., \& Harris, K. (2015). Developing and optimising the use of logic models in systematic reviews: Exploring practice and good practice in the use of programme theory in reviews. PLoS One, 10, 1-26. http://doi.org/10.1371/journal.pone.0142187

Kong, Z., Sze, T. M., Yu, J. J., Loprinzi, P. D., Xiao, T., Yeung, A. S., ... Zou, L. (2019). Tai chi as an alternative exercise to improve physical fitness for children and adolescents with intellectual disability. International Journal of Environmental Research and Public Health, 16, 1-12. doi:10.3390/ijerph16071152

Krahn, G. L., \& Fox, M. H. (2015). Health Disparities of People with Intellectual Disabilities: Journal of Applied Research in Intellectual Disabilities, 27, 431-446. doi:10.1111/jar.12067.Health

Lee, K., Lee, M., \& Song, C. (2016). Balance training improves postural balance, gait, and functional strength in adolescents with intellectual disabilities: Single-blinded, randomized clinical trial. Disability and Health Journal, 9, 416-422. doi:10.1016/j.dhjo.2016.01.010 
Lennox, N., McPherson, L., Bain, C., O’Callaghan, M., Carrington, S., \& Ware, R. S. (2016). A health advocacy intervention for adolescents with intellectual disability: a cluster randomized controlled trial. Developmental Medicine and Child Neurology, 58, 12651272. doi:10.1111/dmen.13174

Maine, A., Dickson, A., Truesdale, M., \& Brown, M. (2017). An application of Bandura's 'Four Sources of Self-Efficacy' to the self-management of type 2 diabetes in people with intellectual disability: An inductive and deductive thematic analysis. Research in Developmental Disabilities, 70, 75-84. http://doi.org/10.1016/j.ridd.2017.09.004

Maine, A., Brown, M. J., Dickson, A., \& Truesdale, M. (2019). Pilot feasibility study of the Walking Away from Diabetes programme for adults with intellectual disabilities in two further education colleges: Process evaluation findings. Journal of Applied Research in Intellectual Disabilities, (September), 1034-1046. http://doi.org/10.1111/jar.12593

Medical Research Council (2019) retrieved from https://mrc.ukri.org/successes/investing-forimpact/priority-challenges/prevention-research/what-is-prevention-research/

Melville, C. A., Cooper, S. A., Morrison, J., Smiley, E., Allan, L., Jackson, A., \& Mantry, D. (2008). The prevalence and incidence of mental ill-health in people with autism and intellectual disabilities. Journal of Autism and Developmental Disorders, 38, 16761688. doi:10.1007/s10803-008-0549-7

Moher, D., Liberati, A., Tetzlaff, J. \& Altman, D. G. (2009). Preferred reporting items for systematic reviews and meta-analyses: The PRISMA statement. PLoS Medicine, 6 (7) 10.1371/journal.pmed.1000097

Ordonez, F. J., Rosety, M. A., Camacho, A., Rosety, I., Diaz, A. J., Fornieles, G., ... RosetyRodriguez, M. (2014). Aerobic training improved low-grade inflammation in obese women with intellectual disability. Journal of Intellectual Disability Research, 5, 583590. doi:10.1111/jir.12056 
O’Shea, M., O'Shea, C., Gibson, L., Leo, J., \& Carty, C. (2018). The prevalence of obesity in children and young people with Down syndrome. Journal of Applied Research in Intellectual Disabilities, 31, 1225-1229. http://doi.org/10.1111/jar.12465

Scottish Commission of Learning Disabilities (2017). Retreived from: https://www.scld.org.uk/

Shields, N., Taylor, N. F., Wee, E., Wollersheim, D., O’Shea, S. D., \& Fernhall, B. (2013). A community-based strength training programme increases muscle strength and physical activity in young people with Down syndrome: A randomised controlled trial. Research in Developmental Disabilities, 34, 4385-4394. doi:10.1016/j.ridd.2013.09.022

Sobol, G. S.; Rabinowitz, J.; Gross, R. (2013). School-based obesity prevention programs: A meta-analysis of randomized controlled trials. Obesity, 21, 2422-2428.

Stanish, H., \& Temple, V. (2012). Efficacy of peer-guided exercise programme for adolescents with intellectual disability. Journal of Applied Research in Intellectual Disabilities, 25, $319-328$

Trollor, J. N., Salomon, C., \& Franklin, C. (2016). Prescribing psychotropic drugs to people with an intellectual disability. Australian Prescriber, 39, 126-130. doi:10.18773/austprescr.2016.048

Truesdale, M., \& Brown, M. (2017). People with Learning Disabilities in Scotland: 2017 Health Needs Assessment Update Report. NHS Health Scotland

Yates, T., Edwardson, C. L., Henson, J., Gray, L. J., Ashra, N. B., Troughton, J., ... Davies, M. J. (2016). Walking Away from Type 2 diabetes : a cluster randomized controlled trial. Diabetic Medicine, 34, 698-707. http://doi.org/10.1111/dme.13254

World Health Organisation (2013). Definition of key terms. Retrieved from: https://www.who.int/hiv/pub/guidelines/arv2013/intro/keyterms/en/ 
World Health Organisation (2017), Global Action Plan for the Prevention and Control of Noncommunicable Diseases 2013-2020, World Health Organisation, Geneva. Retrieved from: https://apps.who.int/iris/handle/10665/94384

Wu, W. L., Yang, Y. F., Chu, I. H., Hsu, H. T., Tsai, F. H., \& Liang, J. M. (2017). Effectiveness of a cross-circuit exercise training program in improving the fitness of overweight or obese adolescents with intellectual disability enrolled in special education schools. Research in Developmental Disabilities, 60, 83-95. doi:10.1016/j.ridd.2016.11.005

\section{Conflict of Interest}

The authors have no conflict of interest to declare. 
Table 1. Study characteristics

\begin{tabular}{|c|c|c|c|c|c|c|c|}
\hline Study & Aims/design & $\begin{array}{l}\text { Intervention } \\
\text { setting and } \\
\text { techniques }\end{array}$ & Participants & Measures & Results & Recommendations & $\begin{array}{l}\text { Global } \\
\text { EPHPP } \\
\text { rating }\end{array}$ \\
\hline $\begin{array}{l}\text { Elmahgoub et al. } \\
\text { (2009) } \\
\text { Belgium }\end{array}$ & $\begin{array}{l}\text { Investigating } \\
\text { the effects of } \\
\text { combined } \\
\text { exercise training } \\
\text { on physical } \\
\text { health, physical } \\
\text { fitness and lipid } \\
\text { profile in } \\
\text { adolescents } \\
\text { with ID } \\
\text { Powered: No } \\
\text { Randomized: } \\
\text { Yes } \\
\text { Control: Yes }\end{array}$ & $\begin{array}{l}\text { Gym } \\
\text { Strength } \\
\text { training using } \\
\text { stack weights } \\
\text { Aerobic } \\
\text { training using } \\
\text { cycling and } \\
\text { steps }\end{array}$ & $\begin{array}{l}\begin{array}{l}\text { Special } \\
\text { education } \\
\text { school }\end{array} \\
\text { Adolescents } \\
\text { with IDD } \\
(N=30) \\
\text { Age 14-22 } \\
\text { years } \\
\text { Gender not } \\
\text { specified } \\
\text { Disability: } \\
\text { non-specific: } \\
26.7 \% \text {; } \\
\text { Fragile X } \\
26.7 \% \text {; } \\
\text { Autism } 46.7 \% \\
\text { Ethnicity: Not } \\
\text { specified }\end{array}$ & $\begin{array}{l}\text { Height, weight, } \\
\text { wait circumference } \\
\text { Lipid profile } \\
\text { Cardiovascular } \\
\text { fitness } \\
\text { Sit to stand test } \\
\text { Hand grip strength } \\
\text { Muscle fatigue test }\end{array}$ & $\begin{array}{l}100 \% \text { attendance } \\
\text { Significant } \\
\text { improvements } \\
\text { across all } \\
\text { outcomes }(\mathrm{P}= \\
0.05)\end{array}$ & None stated & Moderate \\
\hline $\begin{array}{l}\text { Stanish and } \\
\text { Temple (2011) } \\
\text { U.S. }\end{array}$ & $\begin{array}{l}\text { Evaluation of } \\
\text { efficacy of a } \\
\text { peer-guided } \\
\text { exercise } \\
\text { programme }\end{array}$ & $\begin{array}{l}\text { Gym } \\
\text { Strength } \\
\text { training using } \\
\text { stack weights }\end{array}$ & $\begin{array}{l}\text { YMCA } \\
\text { (community } \\
\text { setting) } \\
\text { Young people } \\
\text { and people and } \\
\text { adolescents }\end{array}$ & $\begin{array}{l}\text { Attendance and } \\
\text { exercise } \\
\text { engagement: } \\
\text { Programme } \\
\text { attendance and } \\
\text { monitored by } \\
\text { fitness instructors }\end{array}$ & $\begin{array}{l}89.5 \% \text { attendance } \\
\text { All quantitative } \\
\text { changes } \\
\text { statistically } \\
\text { unclear or } \\
\text { insignificant }\end{array}$ & $\begin{array}{l}\text { Specific programme } \\
\text { improvements: } \\
\text { Additional time to } \\
\text { complete exercises; } \\
\text { extended overall } \\
\text { programme; use of } \\
\text { heart rate monitors }\end{array}$ & Weak \\
\hline
\end{tabular}




\begin{tabular}{|c|c|c|c|c|c|c|c|}
\hline & $\begin{array}{l}\text { for adolescents } \\
\text { with intellectual } \\
\text { disability } \\
\text { Powered: No } \\
\text { Randomized: } \\
\text { No } \\
\text { Control: No }\end{array}$ & $\begin{array}{l}\text { Aerobic } \\
\text { training using } \\
\text { machines } \\
\text { Physio-guided } \\
\text { stretching and } \\
\text { core strength } \\
\text { training } \\
\text { Peer support }\end{array}$ & $\begin{array}{l}\begin{array}{l}\text { with ID }(N= \\
20)\end{array} \\
\text { Age: } 15-21 \\
\text { (mean } 17.8, \\
\text { SD 1.6) years } \\
\text { Females 50\% } \\
\text { Disability: } \\
\text { Down } \\
\text { syndrome, } \\
\text { Williams } \\
\text { syndrome, } \\
\text { cerebral palsy } \\
\text { and } \\
\text { unspecified } \\
\text { (group } \\
\text { numbers not } \\
\text { provided) } \\
\text { Ethnicity: Not } \\
\text { specified }\end{array}$ & & $\begin{array}{l}\text { Qualitative data } \\
\text { included themes } \\
\text { of health gains, } \\
\text { social gains and } \\
\text { programmes } \\
\text { which fit }\end{array}$ & $\begin{array}{l}\text { to objectively } \\
\text { monitor exercise } \\
\text { intensity; } \\
\text { training for peer } \\
\text { support }\end{array}$ & \\
\hline $\begin{array}{l}\text { Jankowicz- } \\
\text { Szymanska et al. } \\
(2012) \\
\text { Poland }\end{array}$ & $\begin{array}{l}\text { Exploring the } \\
\text { effects of a } \\
\text { three-month } \\
\text { sensorimotor } \\
\text { training } \\
\text { programme on } \\
\text { static balance in } \\
\text { young people } \\
\text { with ID } \\
\text { Powered: No }\end{array}$ & $\begin{array}{l}\text { Gym } \\
\text { Balance } \\
\text { training using } \\
\text { rehabilitation } \\
\text { balls, air } \\
\text { pillows, } \\
\text { exercises in } \\
\text { balance } \\
\text { positions }\end{array}$ & $\begin{array}{l}\begin{array}{l}\text { Special } \\
\text { education care } \\
\text { centre }\end{array} \\
\text { Young people } \\
\text { with mild ID } \\
(N=40) \\
\text { Age: } 16-18 \\
\text { (mean } 16.8) \\
\text { years }\end{array}$ & $\begin{array}{l}\text { Height, weight, } \\
\text { BMI } \\
\text { Static balance }\end{array}$ & $\begin{array}{l}\text { Attendance rates } \\
\text { not reported } \\
\text { Improvements in } \\
\text { experimental } \\
\text { group were noted } \\
\text { but not significant }\end{array}$ & $\begin{array}{l}\text { Exercise } \\
\text { programmes for } \\
\text { persons with IDD } \\
\text { should be } \\
\text { supplemented by } \\
\text { sensorimotor } \\
\text { exercises }\end{array}$ & Moderate \\
\hline
\end{tabular}




\begin{tabular}{|c|c|c|c|c|c|c|c|}
\hline & $\begin{array}{l}\text { Randomized: } \\
\text { Yes } \\
\text { Control: Yes } \\
\text { Powered: Yes } \\
\text { Randomized: } \\
\text { Yes } \\
\text { Control: Yes }\end{array}$ & & $\begin{array}{l}\text { Females: } 50 \% \\
\text { Disability: } \\
\text { Down } \\
\text { syndrome was } \\
\text { the cause of } \\
\text { mild } \\
\text { retardation } \\
\text { (group } \\
\text { numbers not } \\
\text { provided) } \\
\text { Ethnicity: Not } \\
\text { specified }\end{array}$ & & & & \\
\hline $\begin{array}{l}\text { Curtin et al. } \\
\text { (2013) } \\
\text { U.S. }\end{array}$ & $\begin{array}{l}\text { Assessing } \\
\text { impact of } \\
\text { parental } \\
\text { education in a } \\
\text { weight loss } \\
\text { intervention for } \\
\text { young people } \\
\text { with ID. }\end{array}$ & $\begin{array}{l}\text { Home/research } \\
\text { centre } \\
\text { Diet plan made } \\
\text { in consultation } \\
\text { with parents } \\
\text { Parents } \\
\text { instructed on } \\
\text { diet } \\
\text { implementation } \\
\text { Dietician-led } \\
\text { nutrition } \\
\text { education } \\
\text { sessions } \\
\text { Therapeutic } \\
\text { recreation-led } \\
\text { physical } \\
\text { activity } \\
\text { education } \\
\text { sessions }\end{array}$ & $\begin{array}{l}\text { University } \\
\text { Young people } \\
\text { with Down } \\
\text { syndrome ( } N= \\
21) \\
\text { Age: } 16-18 \\
\text { (mean 20.5, } \\
\text { SD 3.2) years } \\
\text { Females: } 81 \% \\
\text { Disability: } \\
\text { Down } \\
\text { syndrome: } \\
\text { 100\% } \\
\text { Ethnicity: } \\
\text { White: } 95 \% \\
\text { Hispanic: } 4.8 \%\end{array}$ & $\begin{array}{l}\text { Mean changes in } \\
\text { levels of physical } \\
\text { activity, weight } \\
\text { and percentage of } \\
\text { body fat } \\
\text { Dietary behaviours } \\
\text { (consumption of } \\
\text { fruits and } \\
\text { vegetables) }\end{array}$ & $\begin{array}{l}\text { Lower body } \\
\text { weight in } \\
\text { intervention } \\
\text { group; } \mathrm{P}=.005) \\
\text { Increases in } \\
\text { physical activity } \\
\text { in intervention } \\
(\mathrm{P}=0.002) \\
\text { Dietary changes } \\
\text { not significant }\end{array}$ & $\begin{array}{l}\text { Monthly individual } \\
\text { counselling } \\
\text { Focus on aerobic } \\
\text { activities to } \\
\text { decrease sedentary } \\
\text { behaviour } \\
\text { Utilization of } \\
\text { common goals } \\
\text { across stakeholders }\end{array}$ & Moderate \\
\hline
\end{tabular}




\begin{tabular}{|c|c|c|c|c|c|c|c|}
\hline $\begin{array}{l}\text { Shields et al. } \\
\text { (2013) } \\
\text { Australia }\end{array}$ & $\begin{array}{l}\text { Investigating } \\
\text { the effects of a } \\
\text { student-led } \\
\text { resistance } \\
\text { training } \\
\text { programme in } \\
\text { adolescents and } \\
\text { young people } \\
\text { with Down } \\
\text { syndrome } \\
\text { Powered: No } \\
\text { Randomized: } \\
\text { Yes } \\
\text { Control: Yes }\end{array}$ & $\begin{array}{l}\text { Gym } \\
\text { Resistance } \\
\text { training using } \\
\text { weight } \\
\text { machines }\end{array}$ & $\begin{array}{l}\text { Community } \\
\text { Gym } \\
\text { Adolescents } \\
\text { and young } \\
\text { people with } \\
\text { Down } \\
\text { syndrome ( } N= \\
68 \text { ) } \\
\text { Age: mean } \\
17.9 \text {, SD } 2.6 \\
\text { years } \\
\text { Females: } 41 \% \\
\text { Down } \\
\text { syndrome: } \\
100 \% \\
\text { Ethnicity: Not } \\
\text { specified }\end{array}$ & $\begin{array}{l}\text { Work performance } \\
\text { (Simulated work } \\
\text { test) } \\
\text { Muscle strength } \\
\text { (one-repetition } \\
\text { maximum force } \\
\text { generation tests) } \\
\text { Physical activity } \\
\text { levels } \\
\text { (Accelerometer) } \\
\text { Social activities } \\
\text { (Control group) }\end{array}$ & $\begin{array}{l}92 \% \text { Attendance } \\
\text { Significant } \\
\text { increase over } \\
\text { social group in } \\
\text { muscle strength } \\
\text { (95\% CI 3-11; } \\
\text { SMD 0.8) } \\
\text { and physical } \\
\text { activity (95\% CI } \\
5-112 ; \text { SMD 0.8) } \\
\text { in later weeks } \\
\text { No difference in } \\
\text { work performance }\end{array}$ & None stated & Strong \\
\hline $\begin{array}{l}\text { Hinkson et al. } \\
\text { (2013) } \\
\text { "MEND" (Mind, } \\
\text { nutrition, Do it) } \\
\text { New Zealand }\end{array}$ & $\begin{array}{l}\text { Evaluating } \\
\text { effectiveness of } \\
\text { a program } \\
\text { managing } \\
\text { weight through } \\
\text { changes in } \\
\text { physical activity } \\
\text { and nutrition } \\
\text { behaviours in } \\
\text { overweight and } \\
\text { obese NZ } \\
\text { children and } \\
\text { youth with IDD }\end{array}$ & $\begin{array}{l}\text { School } \\
\text { Classroom } \\
\text { based physical } \\
\text { activity } \\
\text { sessions }\end{array}$ & $\begin{array}{l}\begin{array}{l}\text { Special needs } \\
\text { schools }\end{array} \\
\text { Children and } \\
\text { youth with } \\
\text { IDD }(N=17) \\
\text { Aged } 7+\text { years } \\
\text { Females 41\% } \\
\text { Disability: }\end{array}$ & $\begin{array}{l}\text { Diet and nutrition } \\
\text { questionnaire } \\
\text { Parent nutrition } \\
\text { questionnaire } \\
\text { Ambulatory } \\
\text { activity } \\
\text { Height, weight, } \\
\text { BMI } \\
\text { t-tests for all above }\end{array}$ & $\begin{array}{l}\text { Attendance rates } \\
\text { not reported } \\
\text { All quantitative } \\
\text { changes } \\
\text { statistically } \\
\text { unclear or } \\
\text { insignificant } \\
\text { Attendance rates } \\
\text { not reported }\end{array}$ & $\begin{array}{l}\text { Programme specific } \\
\text { ally tailored to the } \\
\text { needs of young } \\
\text { people with IDD } \\
\text { Focus on healthy } \\
\text { living rather than } \\
\text { obesity } \\
\text { management } \\
\text { Consultation with } \\
\text { family and }\end{array}$ & Weak \\
\hline
\end{tabular}




\begin{tabular}{|c|c|c|c|c|c|c|c|}
\hline & $\begin{array}{l}\text { Pre- and post- } \\
\text { measures } \\
\text { Powered: No } \\
\text { Randomized: } \\
\text { No }\end{array}$ & & $\begin{array}{l}\text { global } \\
\text { developmental } \\
\text { delay } 23.5 \% \text {; } \\
\text { autism } 41.2 \% \text {; } \\
\text { Down } \\
\text { syndrome } \\
11.8 \% \text {; } \\
\text { intellectual } \\
\text { disability: } \\
17.6 \% \\
\text { Ethnicity: Not } \\
\text { specified }\end{array}$ & $\begin{array}{l}\text { Semi-structured } \\
\text { interviews }\end{array}$ & $\begin{array}{l}\text { Qualitative data } \\
\text { included themes } \\
\text { of health gains, } \\
\text { social gains and } \\
\text { programmes } \\
\text { which fit }\end{array}$ & $\begin{array}{l}\text { community } \\
\text { important } \\
\text { School is most } \\
\text { suitable setting } \\
\text { Information should } \\
\text { be tailored to } \\
\text { individuals and } \\
\text { delivered by those } \\
\text { with IDD specialist } \\
\text { training } \\
\text { Appropriate } \\
\text { required to } \\
\text { determine physical } \\
\text { activity, nutrition } \\
\text { and health } \\
\text { behaviours in young } \\
\text { people with IDD } \\
\text { Future research } \\
\text { should consider } \\
\text { qualitative and } \\
\text { Quantitative data } \\
\text { plus cost analysis }\end{array}$ & \\
\hline $\begin{array}{l}\text { Ordonez et al. } \\
(2014) \\
\text { Spain }\end{array}$ & $\begin{array}{l}\text { Assessing the } \\
\text { influence of } \\
\text { aerobic training } \\
\text { on obesity in } \\
\text { women with } \\
\text { Down } \\
\text { syndrome. }\end{array}$ & $\begin{array}{l}\text { Gym } \\
\text { Aerobic } \\
\text { training using } \\
\text { treadmills }\end{array}$ & $\begin{array}{l}\text { Community } \\
\text { support groups } \\
\text { Women with } \\
\text { Down } \\
\text { syndrome }(N= \\
20)\end{array}$ & $\begin{array}{l}\text { Body fat \% and } \\
\text { distribution } \\
\text { Anthropometric } \\
\text { measures, } \\
\text { including } \\
\text { plasmatic levels }\end{array}$ & 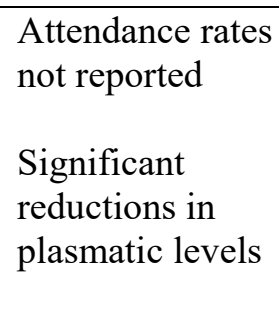 & $\begin{array}{l}\text { Robust, longitudinal } \\
\text { studies are required }\end{array}$ & Moderate \\
\hline
\end{tabular}




\begin{tabular}{|c|c|c|c|c|c|c|c|}
\hline & $\begin{array}{l}\text { Powered: No } \\
\text { Randomized: } \\
\text { Yes } \\
\text { Control: No }\end{array}$ & & $\begin{array}{l}\text { Age: } 18-30 \\
\text { Females: } 100 \% \\
\text { Down } \\
\text { syndrome: } \\
100 \% \\
\text { Ethnicity: Not } \\
\text { specified }\end{array}$ & & & & \\
\hline $\begin{array}{l}\text { Chen et al. (2015) } \\
\text { U.S. }\end{array}$ & $\begin{array}{l}\text { Investigating } \\
\text { the impact of a } \\
\text { single exercise } \\
\text { intervention on } \\
\text { executive } \\
\text { function in } \\
\text { young people } \\
\text { with Down } \\
\text { syndrome } \\
\text { Powered: No } \\
\text { Randomized: } \\
\text { Yes } \\
\text { Control: Yes }\end{array}$ & $\begin{array}{l}\text { Laboratory } \\
\text { (Aerobic } \\
\text { training using } \\
\text { treadmills) }\end{array}$ & $\begin{array}{l}\text { Recruited from } \\
\text { Special } \\
\text { Olympics team } \\
\text { (took place in } \\
\text { sports lab) } \\
\text { Young people } \\
\text { with Down } \\
\text { syndrome ( } N= \\
20 \text { ) } \\
\text { Age: mean } 23 \\
\text { Females } 30 \% \\
\text { Down } \\
\text { syndrome: } \\
100 \% \\
\text { Ethnicity: Not } \\
\text { specified }\end{array}$ & $\begin{array}{l}\text { Measures of } \\
\text { executive function- } \\
\text { related behaviours }\end{array}$ & $\begin{array}{l}95.2 \% \text { Attendance } \\
\begin{array}{l}\text { Non-significant } \\
\text { changes in } \\
\text { response times }\end{array} \\
\text { Significant } \\
\text { improvements in } \\
\text { inhibition }\end{array}$ & $\begin{array}{l}\text { Future studies } \\
\text { should use larger } \\
\text { sample sizes, } \\
\text { controlled exercise } \\
\text { intensity, physical } \\
\text { fitness, testing time } \\
\text { after intervention } \\
\text { and the time of the } \\
\text { test (e.g. optimal } \\
\text { time of day for } \\
\text { executive } \\
\text { processing). }\end{array}$ & Strong \\
\hline
\end{tabular}




\begin{tabular}{|c|c|c|c|c|c|c|c|}
\hline $\begin{array}{l}\text { Boer et al. (2014) } \\
\text { Belgium }\end{array}$ & $\begin{array}{l}\text { Evaluating the } \\
\text { effect of sprint } \\
\text { interval training } \\
\text { on metabolic } \\
\text { and physical } \\
\text { fitness in } \\
\text { adolescents and } \\
\text { young people } \\
\text { with ID } \\
\text { Powered: No } \\
\text { Randomized: } \\
\text { Yes } \\
\text { Control: Yes }\end{array}$ & $\begin{array}{l}\text { Special } \\
\text { education } \\
\text { schools (in } \\
\text { physio lab) } \\
\text { Aerobic } \\
\text { training using } \\
\text { treadmills }\end{array}$ & 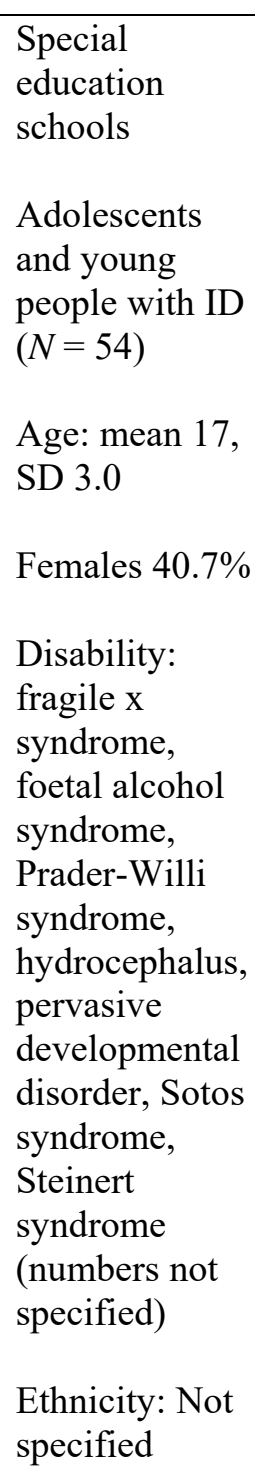 & $\begin{array}{l}\text { Height, weight, } \\
\text { BMI, waist } \\
\text { circumference } \\
\text { Physical activity } \\
\text { (cardiopulmonary } \\
\text { using cyclo- } \\
\text { ergometer) } \\
\text { Blood pressure and } \\
\text { lipid profile } \\
6 \text { minute walk test } \\
\text { Sit to stand test } \\
\text { Muscle fatigue } \\
\text { resistance }\end{array}$ & $\begin{array}{l}85 \% \text { Attendance } \\
\text { Significant } \\
\text { reductions in } \\
\text { intervention group } \\
\text { in waist } \\
\text { circumference (P } \\
<0.01 \text { ); blood } \\
\text { pressure; insulin } \\
\text { levels ( }<0.01 \text { ); } \\
\text { lipids (LDL only - } \\
\mathrm{P}<0.01) \\
\text { Significant } \\
\text { increases in } \\
\text { cardiopulmonary } \\
\text { measures ( } \mathrm{P}< \\
0.01 \text { ) }\end{array}$ & $\begin{array}{l}\text { Further research } \\
\text { with sprint interval } \\
\text { and resistance } \\
\text { training should be } \\
\text { conducted } \\
\text { Similar research } \\
\text { could be carried out } \\
\text { with homogenous } \\
\text { groups such as } \\
\text { people with DS or } \\
\text { Fragile X }\end{array}$ & Strong \\
\hline
\end{tabular}




\begin{tabular}{|c|c|c|c|c|c|c|c|}
\hline $\begin{array}{l}\text { Hubbard et al. } \\
\text { (2015) } \\
\text { U.S. } \\
\text { "Smarter } \\
\text { Lunchroom" }\end{array}$ & $\begin{array}{l}\text { Assessing } \\
\text { impact of a } \\
\text { school based } \\
\text { diet intervention } \\
\text { programme } \\
\text { Powered: No } \\
\text { Randomized: } \\
\text { No } \\
\text { Control: No }\end{array}$ & $\begin{array}{l}\text { Residential } \\
\text { school } \\
\text { Social story } \\
\text { preparation } \\
\text { Environmental } \\
\text { changes } \\
\text { (layout of } \\
\text { canteen food } \\
\text { options) }\end{array}$ & $\begin{array}{l}\begin{array}{l}\text { Specialized } \\
\text { residential } \\
\text { school } \\
\text { (private) }\end{array} \\
\text { Students with } \\
\text { IDD }(N=43) \\
\text { Age: } 11-22 \\
\text { (mean 18.3, } \\
\text { SD 2.5) } \\
\text { Females 51\% } \\
\text { Disability: Not } \\
\text { specified } \\
\text { Ethnicity: Not } \\
\text { specified }\end{array}$ & $\begin{array}{l}\text { Digital } \\
\text { photography of } \\
\text { foods: selection } \\
\text { and plate waste }\end{array}$ & $\begin{array}{l}100 \% \text { Attendance } \\
\text { Significant } \\
\text { increases in } \\
\text { healthy foods, } \\
\text { including whole } \\
\text { grains }(\mathrm{P}=0.005) \\
\text { and fruits }(\mathrm{P}= \\
0.008) . \\
\text { Significant } \\
\text { decreases in fruit } \\
((\mathrm{P}=0.04) \text { and } \\
\text { vegetables }(\mathrm{P}= \\
0.03) .\end{array}$ & $\begin{array}{l}\text { Future research } \\
\text { should assess long- } \\
\text { term dietary change } \\
\text { adherence and } \\
\text { explore programme } \\
\text { in other educational } \\
\text { settings }\end{array}$ & Weak \\
\hline $\begin{array}{l}\text { Netherlands } \\
\text { "PREPARED ON } \\
\text { TIME" }\end{array}$ & $\begin{array}{l}\text { Evaluating } \\
\text { efficacy of an e- } \\
\text { learning } \\
\text { program for } \\
\text { students with ID } \\
\text { in secondary } \\
\text { special-needs } \\
\text { schools and } \\
\text { examining } \\
\text { tobacco and } \\
\text { alcohol use for } \\
\text { this population } \\
\text { Powered: No } \\
\text { Randomized: } \\
\text { Yes }\end{array}$ & $\begin{array}{l}\text { Classroom } \\
\text { based } \\
\text { Educational } \\
\text { sessions which } \\
\text { focus on } \\
\text { attitude-social } \\
\text { influence-- } \\
\text { efficacy mode }\end{array}$ & $\begin{array}{l}\begin{array}{l}\text { Special needs } \\
\text { schools }\end{array} \\
\text { Students with } \\
\text { mild and } \\
\text { borderline ID } \\
(N=254) \\
\text { Age: } 12-15 \\
\text { (mean 13.6) } \\
\text { Females } 42.4 \% \\
\text { Disability: Not } \\
\text { specified }\end{array}$ & $\begin{array}{l}\text { Baseline } \\
\text { questionnaires on } \\
\text { lifestyle } \\
\text { behaviours }\end{array}$ & $\begin{array}{l}\text { Attendance rates } \\
\text { not reported } \\
\text { Respondents had } \\
\text { initiated smoking } \\
(49 \%) \text { and } \\
\text { drinking }(75 \%) \\
\text { beyond } \\
\text { expectations } \\
\text { "PREPARED ON } \\
\text { TIME" did not } \\
\text { affect the } \\
\text { behavioural } \\
\text { determinants }\end{array}$ & $\begin{array}{l}\text { Intervention should } \\
\text { include additional } \\
\text { training such as } \\
\text { refusal and social } \\
\text { skills. } \\
\text { Frequent repetition } \\
\text { of didactic material } \\
\text { Parental } \\
\text { involvement }\end{array}$ & Moderate \\
\hline
\end{tabular}




\begin{tabular}{|c|c|c|c|c|c|c|c|}
\hline & Control: Yes & & $\begin{array}{l}\text { Ethnicity: Not } \\
\text { specified }\end{array}$ & & & & \\
\hline $\begin{array}{l}\text { Lennox et al. } \\
\text { (2016) } \\
\text { Australia } \\
\text { "Ask health } \\
\text { diary" and } \\
\text { "Comprehensive } \\
\text { Health } \\
\text { Assessment } \\
\text { Program } \\
\text { (CHAP)" }\end{array}$ & $\begin{array}{l}\text { Assessing a } \\
\text { health } \\
\text { intervention } \\
\text { package } \\
\text { promoting } \\
\text { health and } \\
\text { detecting } \\
\text { disease in } \\
\text { adolescents } \\
\text { with ID } \\
\text { Powered: Yes } \\
\text { Randomized: } \\
\text { Yes } \\
\text { Control: No } \\
\text { (randomization } \\
\text { of school } \\
\text { selection) }\end{array}$ & $\begin{array}{l}\text { Classroom } \\
\text { Health } \\
\text { promotion } \\
\text { diary with } \\
\text { education } \\
\text { sessions }\end{array}$ & $\begin{array}{l}\text { Special } \\
\text { education } \\
\text { schools } \\
\text { Adolescents } \\
\text { with ID }(N= \\
592 \\
\text { Age: mean } \\
\text { 15.5, SD } 1.6 \\
\text { Females: } \\
45.4 \% \\
\text { Disability: Not } \\
\text { specified } \\
\text { Ethnicity: Not } \\
\text { specified }\end{array}$ & $\begin{array}{l}\text { CHAP compared } \\
\text { to previous years } \\
\text { GP records, with } \\
\text { vision and hearing } \\
\text { as primary } \\
\text { outcomes }\end{array}$ & $\begin{array}{l}38 \% \text { Attendance } \\
\text { Testing more } \\
\text { likely in } \\
\text { intervention group } \\
\text { for vision (odds } \\
\text { ratio [OR] 3.3; } \\
95 \% \text { confidence } \\
\text { interval [CI] } 1.8- \\
6.1) \text {; hearing (OR } \\
2.7 ; 95 \% \text { CI } 1.0- \\
7.3) ; \text { blood } \\
\text { pressure change } \\
\text { (OR 2.4; } 95 \% \mathrm{CI} \\
1.6-3.7) \text {; and } \\
\text { weight recorded } \\
\text { (OR 4.8; } 95 \% \mathrm{CI} \\
3.1-7.6)\end{array}$ & $\begin{array}{l}\text { Programme should } \\
\text { be delivered to } \\
\text { adolescents } \\
\text { Long term health } \\
\text { risk reduction } \\
\text { should be studied }\end{array}$ & Weak \\
\hline Wu et al. (2017) & $\begin{array}{l}\text { Assessing } \\
\text { effects of a } \\
\text { cross-circuit } \\
\text { training } \\
\text { intervention } \\
\text { program for } \\
\text { obese or } \\
\text { overweight } \\
\text { students with ID } \\
\text { Powered: No }\end{array}$ & $\begin{array}{l}\text { Gym } \\
\text { Cross-circuit } \\
\text { training } \\
\text { Treadmill, step } \\
\text { machine, cross } \\
\text { trainer, and } \\
\text { stationary } \\
\text { bicycle }\end{array}$ & $\begin{array}{l}\begin{array}{l}\text { Special } \\
\text { education } \\
\text { school }\end{array} \\
\text { Adolescents } \\
\text { with ID }(N= \\
43) \\
\text { Age: } 13-19 \\
\text { (mean 16.9, } \\
\text { SD 1.35) }\end{array}$ & $\begin{array}{l}\text { Height, weight, } \\
\text { heart rate, body } \\
\text { composition, } \\
\text { dynamic balance } \\
\text { 1-min sit-ups, } \\
\text { anaerobic test } \\
\text { Cardiorespiratory } \\
\text { fitness }\end{array}$ & $\begin{array}{l}\text { Attendance rates } \\
\text { not reported } \\
\text { Significant } \\
\text { differences in } \\
\text { weight, BMI, } \\
\text { body fat mass, } \\
\text { and body fat } \\
\text { percentage } \\
\text { between normal } \\
\text { weight group }\end{array}$ & $\begin{array}{l}\text { Weight training } \\
\text { interventions aimed } \\
\text { at muscle strength } \\
\text { improvement } \\
\text { should be provided } \\
\text { to adolescents with } \\
\text { ID } \\
\text { Future studies } \\
\text { should include } \\
\text { eyes-closed balance } \\
\text { training, together }\end{array}$ & Weak \\
\hline
\end{tabular}




\begin{tabular}{|c|c|c|c|c|c|c|c|}
\hline & $\begin{array}{l}\text { Randomized: } \\
\text { No } \\
\text { Control: Yes }\end{array}$ & & $\begin{array}{l}\text { Females } 42 \% \\
\text { Disability: } \\
\text { reported as } \\
\text { secondary } \\
\text { conditions to } \\
\text { ID - } \\
\text { Down } \\
\text { syndrome: } \\
16.3 \% \text {, vocal } \\
\text { dysfunction: } \\
9.3 \% \text {, autism: } \\
6.9 \% \text { mental } \\
\text { disorder: } 2.3 \% \\
\text { Ethnicity: Not } \\
\text { specified }\end{array}$ & & $\begin{array}{l}\text { other groups }(\mathrm{p}< \\
0.05) \text {. }\end{array}$ & $\begin{array}{l}\text { with vestibular and } \\
\text { proprioception } \\
\text { stimulation to } \\
\text { improve the balance } \\
\text { performance of } \\
\text { people with ID }\end{array}$ & \\
\hline $\begin{array}{l}\text { Lee et al. (2016) } \\
\text { South Korea }\end{array}$ & $\begin{array}{l}\text { Exploring the } \\
\text { effects of } \\
\text { balance training } \\
\text { on postural } \\
\text { balance, gait, } \\
\text { and functional } \\
\text { strength in } \\
\text { adolescents } \\
\text { with intellectual } \\
\text { disabilities } \\
\text { Powered: No } \\
\text { Randomized: } \\
\text { Yes } \\
\text { Control: Yes }\end{array}$ & $\begin{array}{l}\text { Not specified } \\
\text { Balance } \\
\text { training using } \\
\text { balls, balloons } \\
\text { and foam on } \\
\text { balance mats }\end{array}$ & $\begin{array}{l}\begin{array}{l}\text { Special } \\
\text { education } \\
\text { school }\end{array} \\
\text { Adolescents } \\
\text { with ID }(N= \\
32) \\
\text { Age:14-19 } \\
\text { (mean 16.9, } \\
\text { SD 1.70) } \\
\text { Females 43.8\% } \\
\text { Disability: Not } \\
\text { specified }\end{array}$ & $\begin{array}{l}\text { Balance (postural } \\
\text { sway and one leg } \\
\text { test) } \\
\text { Gait } \\
\text { Sit-to-stand test }\end{array}$ & $\begin{array}{l}93.8 \% \text { Attendance } \\
\text { Significant } \\
\text { improvements in } \\
\text { postural balance } \\
\text { and functional } \\
\text { strength in } \\
\text { intervention group } \\
(\mathrm{p}<0.05)\end{array}$ & $\begin{array}{l}\text { Longitudinal } \\
\text { follow-ups. }\end{array}$ & Moderate \\
\hline
\end{tabular}




\begin{tabular}{|c|c|c|c|c|c|c|c|}
\hline & & & $\begin{array}{l}\text { Ethnicity: Not } \\
\text { specified }\end{array}$ & & & & \\
\hline $\begin{array}{l}\text { Maine et al. } \\
\text { (2019) } \\
\text { U.K. }\end{array}$ & $\begin{array}{l}\text { Assessing } \\
\text { feasibility of } \\
\text { delivering a } \\
\text { T2D prevention } \\
\text { programme in } \\
\text { FE colleges } \\
\text { using process } \\
\text { evaluation. } \\
\text { Powered: No } \\
\text { Randomized: } \\
\text { No } \\
\text { Control: No }\end{array}$ & $\begin{array}{l}\text { Two FE } \\
\text { colleges } \\
\text { Educational } \\
\text { sessions } \\
\text { promoting } \\
\text { increased } \\
\text { ambulatory } \\
\text { activity }\end{array}$ & $\begin{array}{l}\text { FE colleges } \\
\text { Young people } \\
\text { with ID ( } N= \\
48) \\
\text { Age: Range } \\
\text { 18-39 years, } \\
\text { Mean } 20.9 \text { (SD } \\
5.02) \\
\text { Females: } \\
37.5 \% \\
\text { Disability: Not } \\
\text { specified } \\
\text { Ethnicity: Not } \\
\text { specified }\end{array}$ & $\begin{array}{l}\text { Focus group } \\
\text { feedback (students } \\
\text { and educators) } \\
\text { Attendance rates } \\
\text { Baseline } \\
\text { ambulatory and } \\
\text { anthropometric } \\
\text { measures } \\
\text { International } \\
\text { physical activity } \\
\text { questionnaire }\end{array}$ & $\begin{array}{l}96 \% \text { participation } \\
\text { rate. } \\
\text { Educational } \\
\text { sessions } \\
\text { positively } \\
\text { received, and } \\
\text { some short-term } \\
\text { impact was } \\
\text { described } \\
62.5 \% \text { of } \\
\text { participants were } \\
\text { obese or } \\
\text { overweight } \\
\text { High levels of } \\
\text { physical inactivity }\end{array}$ & $\begin{array}{l}\text { Adapted version of } \\
\text { programme to be } \\
\text { trialled with FE } \\
\text { college educators } \\
\text { before wider trial }\end{array}$ & Moderate \\
\hline $\begin{array}{l}\text { Kong et al. } \\
(2019) \\
\text { China }\end{array}$ & $\begin{array}{l}\text { Investigating } \\
\text { effects of Tai } \\
\text { Chi on } \\
\text { physical fitness } \\
\text { among children } \\
\text { and adolescents } \\
\text { with ID. } \\
\text { Powered: No } \\
\text { Randomized: } \\
\text { No } \\
\text { Control: Yes }\end{array}$ & $\begin{array}{l}\text { Indoor sports } \\
\text { hall } \\
\text { Tai chi } \\
\text { exercises } \\
\text { modified for } \\
\text { population } \\
\text { One Tai chi } \\
\text { (TC) group, } \\
\text { one aerobic } \\
\text { exercise (AE) } \\
\text { and one control }\end{array}$ & $\begin{array}{l}\text { Two local } \\
\text { special schools } \\
\text { and one } \\
\text { integrated } \\
\text { school } \\
\text { Young people } \\
\text { with ID ( } N= \\
66) \\
\text { Age: Mean } \\
14.9 \text { SD } 2.1 \\
\text { Females }\end{array}$ & 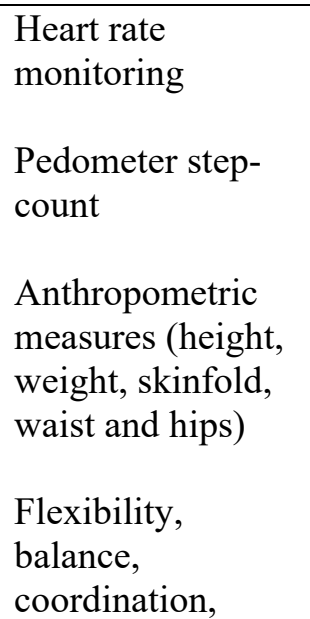 & $\begin{array}{l}60 \% \text { Attendance } \\
\text { AE group: } \\
\text { Significant } \\
\text { changes in body } \\
\text { mass index }(p= \\
0.006, d=0.11) ; \\
\text { sit-ups }(p=0.030 \\
\text { and } d=0.57) ; \\
6 \text {-min walk test (p } \\
=0.005, d= \\
0.89) ;\end{array}$ & $\begin{array}{l}\text { Further rigorous } \\
\text { studies, larger } \\
\text { sample sizes to } \\
\text { validate findings. }\end{array}$ & Strong \\
\hline
\end{tabular}




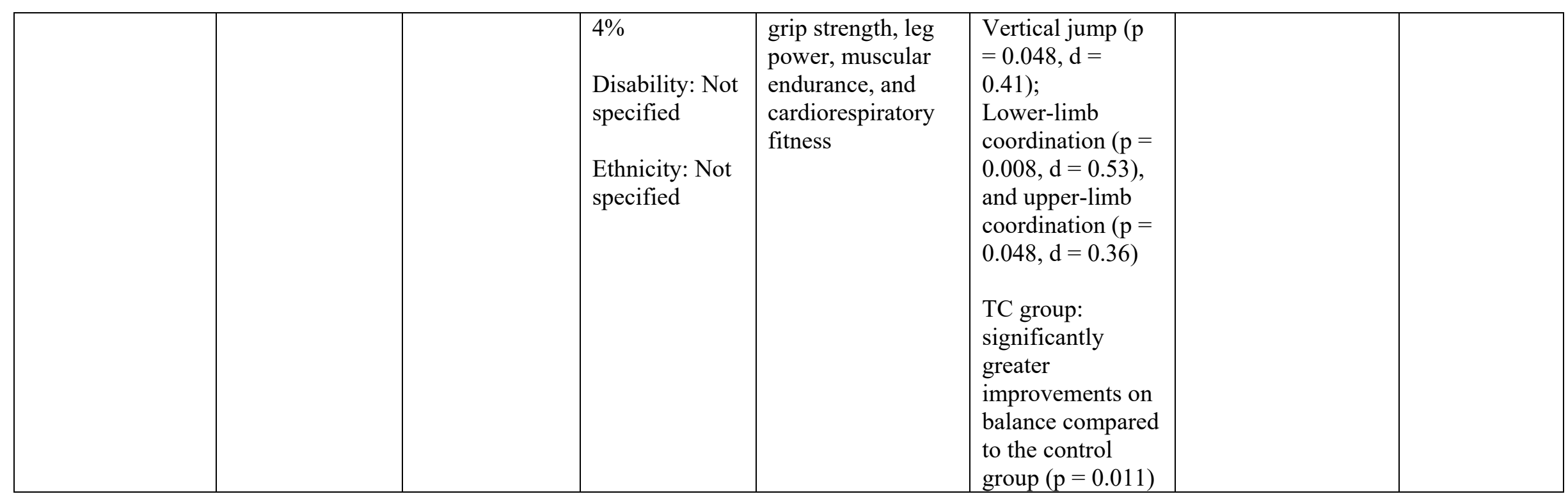


Table 2. Study number matrix

\begin{tabular}{|l|l|}
\hline Study number & \multicolumn{1}{|c|}{ Authors } \\
\hline 1 & Elmahgoub et al. (2009) \\
\hline 2 & Stanish and Temple (2011) \\
\hline 3 & Jankowicz-Szymanska et al. (2012) \\
\hline 4 & Curtin et al. (2013) \\
\hline 5 & Shields et al. (2013) \\
\hline 6 & Hinkson et al. (2013) \\
\hline 7 & Ordonez et al. (2014) \\
\hline 8 & Chen et al. (2015) \\
\hline 9 & Boer et al. (2014) \\
\hline 10 & Hubbard et al. (2015) \\
\hline 11 & Kiewik et al. (2016) \\
\hline 12 & Lennox et al. (2016) \\
\hline 13 & Wu et al. (2017) \\
\hline 14 & Lee et al. (2016) \\
\hline 15 & Maine et al. (2019) \\
\hline 16 & Kong et al. (2019) \\
\hline
\end{tabular}


Table 3. EPHPP global ratings

\begin{tabular}{|c|c|c|c|c|c|c|}
\hline Study & Representativeness & Design & Confounders & $\begin{array}{l}\text { Data } \\
\text { Collection } \\
\text { method }\end{array}$ & $\begin{array}{l}\text { Drop- } \\
\text { outs }\end{array}$ & $\begin{array}{l}\text { Global } \\
\text { rating }\end{array}$ \\
\hline $\begin{array}{l}\text { Elmahgoub } \\
\text { et al. } \\
(2009)\end{array}$ & Moderate & Moderate & Strong & Strong & Weak & Moderate \\
\hline $\begin{array}{l}\text { Stanish } \\
\text { and } \\
\text { Temple } \\
(2012)\end{array}$ & Moderate & Moderate & Weak & Strong & Weak & Weak \\
\hline $\begin{array}{l}\text { Jankowicz- } \\
\text { Szymanska } \\
\text { et al. } \\
(2011)\end{array}$ & Moderate & Moderate & Strong & Strong & Weak & Moderate \\
\hline $\begin{array}{l}\text { Curtin et } \\
\text { al. (2013) }\end{array}$ & Moderate & Moderate & Weak & Strong & Strong & Moderate \\
\hline $\begin{array}{l}\text { Shields et } \\
\text { al. (2013) }\end{array}$ & Moderate & Strong & Strong & Strong & Strong & Strong \\
\hline $\begin{array}{l}\text { Hinkson et } \\
\text { al. (2013) }\end{array}$ & Moderate & Moderate & Weak & Strong & Weak & Weak \\
\hline $\begin{array}{l}\text { Ordonez et } \\
\text { al. (2014) }\end{array}$ & Moderate & Strong & Strong & Strong & Weak & Moderate \\
\hline $\begin{array}{l}\text { Chen et al. } \\
\text { (2015) }\end{array}$ & Moderate & Strong & Strong & Moderate & Moderate & Strong \\
\hline $\begin{array}{l}\text { Boer et al. } \\
(2014)\end{array}$ & Moderate & Moderate & Moderate & Strong & Strong & Strong \\
\hline $\begin{array}{l}\text { Hubbard et } \\
\text { al. (2015) }\end{array}$ & Weak & Moderate & Weak & Moderate & Strong & Weak \\
\hline $\begin{array}{l}\text { Kiewik et } \\
\text { al. (2016) }\end{array}$ & Moderate & Strong & Strong & Weak & Strong & Moderate \\
\hline $\begin{array}{l}\text { Lennox et } \\
\text { al. }(2016)\end{array}$ & Weak & Strong & Strong & Strong & Weak & Weak \\
\hline $\begin{array}{l}\text { Wu et al. } \\
(2017)\end{array}$ & Moderate & Moderate & Weak & Strong & Weak & Weak \\
\hline $\begin{array}{l}\text { Lee et al. } \\
(2016)\end{array}$ & Moderate & Strong & Strong & Strong & Weak & Moderate \\
\hline $\begin{array}{l}\text { Maine et } \\
\text { al. }(2019)\end{array}$ & Moderate & Moderate & Weak & Strong & Strong & Moderate \\
\hline $\begin{array}{l}\text { Kong et al. } \\
(2019)\end{array}$ & Moderate & Strong & Strong & Strong & Mod. & Strong \\
\hline
\end{tabular}

